\title{
Influence of Anxiety, Achievement Motivation and Quality of Exercise Against Achievement Of PPLP Athletes Of North Sumatera
}

\author{
Kurniadi \\ Graduate Student Of Sports Education \\ Kurniadi.Nasution@Gmail.Com
}

\begin{abstract}
This study aims to determine how much influence some psychological factors that affect the achievements of athletes PPLP North Sumatera. The method used in this research is experimental method with Purposive Sampling technique. How to determine the sample is to select / select the athletes who have followed the training / champions who entered in the category has been determined. The number of athletes who already meet the criteria are : 31 people. This research was conducted in June 2018 at PPLP North Sumatera Medan City, North Sumatera. Research subjects amounted to 31 athletes.To obtain the needed data in depth about the performance of PPLP athletes of North Sumatera, it is necessary to document and form a test in the form of Qustionnaire (Questionnaire) closed. The method used is Checklist (list match) The results of this study indicate: anxiety given the influence of $(45 \%)$, achievement motivation $(35 \%)$, quality exercise $(20 \%)$.
\end{abstract}

Keyword - PPLP Athlete of North Sumatera

\section{INTRODUCTION}

PPLP is a part of an integral sports achievement guidance system through a combination of achievement coaching with formal education pathways at school. This system has a strategic position in laying the foundation for building sports achievements in Indonesia at a potential age in order to develop the talent of students in the field of sports. PPLP's contribution to the strength of sports, both regional and national, is huge. A number of athletes who succeeded in scoring Red and White in the international competition were born from PPLP. Therefore, the existence of PPLP as a warehouse for potential young athletes has a very strategic and important role in the breeding of prospective athletes. Sports nurseries through PPLP are done carefully, accurately, and demand joint commitment to achieve maximum results in the future candidates for athletes who are expected to be able to be ambassadors of the country in the international sports arena. The development of PPLP North Sumatra at first only fostered 3 sports until 2017 fostered 13 sports, now 12 branches due to badminton are no longer included. the sports funded by the government from the APBD for PPLD included: Volleyball, Weightlifting, Swimming, Judo, Taekwondo, Whusu. While the sports funded by the National Budget, namely PPLP, includes Football, Athletics, Pencak Silat, Karate, Boxing, Wrestling. Almost all the needs of athletes are facilitated by PPLP, ranging from housing, clothing, food, and pocket money. PPLP North Sumatra actively participated in various events and produced various achievements. The success of North Sumatra PPLP in achieving sports achievements can be seen from the description of the achievements that have been achieved by athletes. Below is an overview of the results of PPLP North Sumatra's achievements in various championships and last year.

TABLE 1. PPLP North Sumatra Achievements in various Championships From 2013-2017

\begin{tabular}{|c|c|c|c|c|c|c|c|c|}
\hline \multirow[b]{2}{*}{ No } & \multirow{2}{*}{ Championship } & \multirow[b]{2}{*}{ Year } & \multirow{2}{*}{ The Place } & \multicolumn{3}{|c|}{ Achievement of Medals } & \multirow{2}{*}{ Rating } & \multirow{2}{*}{ Information } \\
\hline & & & & Gold & Silver & Bronze & & \\
\hline 1 & Internasional & 2015 & Thailand & v & - & 4 & & Karate \\
\hline \multirow{4}{*}{2} & \multirow{4}{*}{ POPNAS } & 2017 & Jateng & 4 & 10 & 16 & 11 & \\
\hline & & 2016 & Jabar & $\sqrt{ }$ & & & & Atletik \\
\hline & & 2015 & Jabar & 6 & 9 & 110 & 10 & \\
\hline & & 2013 & DKI & 6 & 8 & 11 & 12 & \\
\hline \multirow{9}{*}{3} & \multirow{9}{*}{ 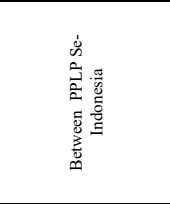 } & \multirow{6}{*}{$\begin{array}{c}2017 \\
\text { (Kejurnas) }\end{array}$} & Sumbar & 2 & 1 & 2 & 5 & Karate \\
\hline & & & $\begin{array}{l}\text { Semarang } \\
\end{array}$ & & & & 1 & Karate \\
\hline & & & & & & & 3 & Karate \\
\hline & & & Jakarta & 3 & 3 & 1 & & Atletik \\
\hline & & & \multirow[t]{2}{*}{ Ambon } & - & 3 & 1 & & B. Volly \\
\hline & & & & - & 3 & 1 & & Taekowndo \\
\hline & & \multirow{3}{*}{2016 (Kejurnas) } & Ambon & - & - & 4 & & Taekwondo \\
\hline & & & Surabaya & 1 & 1 & 2 & & Gulat \\
\hline & & & Maluku & - & - & $\mathrm{V}$ & & S. Bola \\
\hline
\end{tabular}




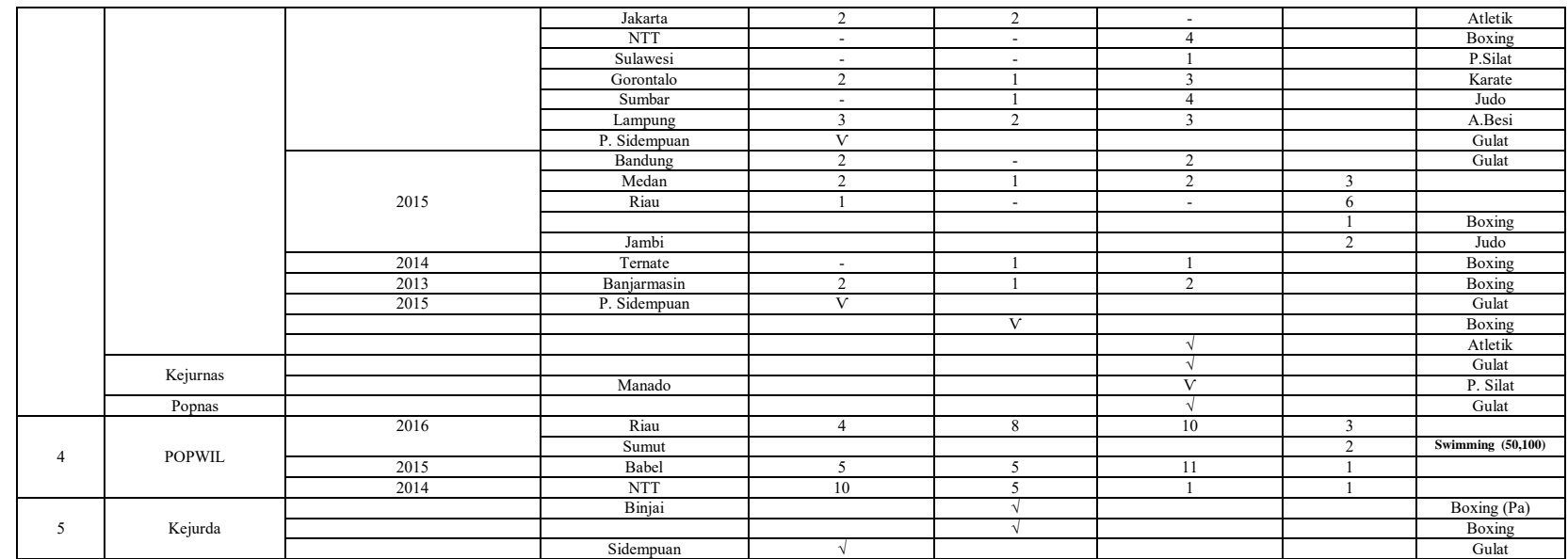

National record breakers in the youth and junior national championships are still around 20 people from 5 built sports, namely: soccer, athletics, wrestling, karate and martial arts. Furthermore there are no achievements that follow, while the number of athletes in the North Sumatra PPLP that has been fostered so far is quite a lot. Subsequently a report from the Ministry of Youth and Sports (Kemenpora) concerning the state of the built sports branches in PPLP North Sumatra that excel in the Regional Championship (Kejurda) from 2010 to 2014.

Figure1. PPLP North Sumatra Sports Branch that excels in the Regional Championship (Kejurda) 2010 - 2014

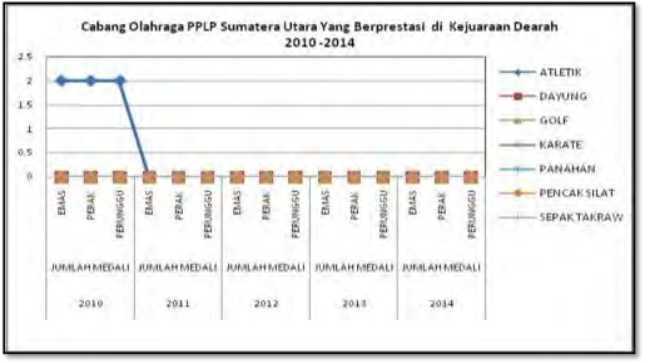

From the table above, there are only a few sports that can contribute medals for PPLP North Sumatra, apart from the sports that have been listed, they have not been able to contribute medals for PPLP North Sumatra and only in 2010 were they able to contribute gold medals for PPLP North Sumatra from several years following event at the Regional Championship (Kejurda). Furthermore, a report from Kemenpora about the North Sumatra PPLP sports branches that excel at the National level in 2010 to 2014
Figure2. The North Sumatra PPLP Athlete Sports Branch who excels at National Championship (National Championship) 2010 - 2014

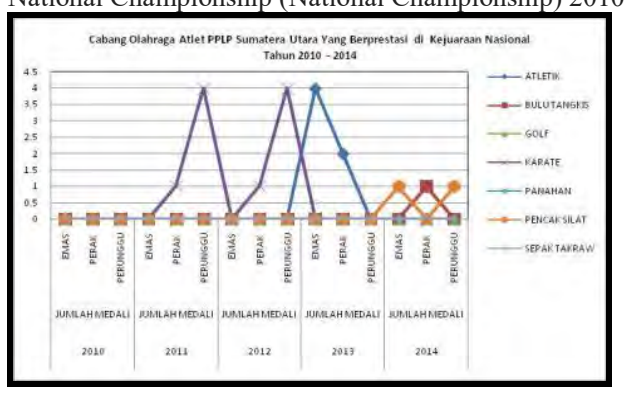

PPLP North Sumatra medal acquisition in the National Championship in 2011 with karate sports successfully contributed silver and bronze medals, and in 2012 the karate sport again succeeded in donating silver and bronze medals. Furthermore, in 2013, PPLP North Sumatra succeeded in contributing gold and bronze medals in athletics, followed by gold and silver medals in the sport of pencak silat while silver medals were donated by badminton in 2014. PPLP North Sumatra won only a few times during the following regional level matches to international level in recent years while the funds spent were quite large.

Observing the table of North Sumatra's PPLP achievement which is decreasing or not maximally above, it is necessary to consider various aspects related to sports performance achievements that certainly influence it, ranging from infrastructure facilities, management, organizations, sports actors including: coaches and athletes, managers, coaching carried out, programs applied, the quality of the athlete's training, and Try Out. Of the various factors that are most important are athletes, because the spearhead of achievement is the athlete himself with various other supporting factors. Besides that the training objectives are directed to the athlete, and in undergoing training the athlete will also feel the effect of the training given to be the champion is required a strong mental. Speaking with sports achievements can not be separated from the word training, because achievement will be achieved only by training there is no shortcut to it. Improving the performance and abilities of an athlete, one of the keys is to do the exercises well. 
In accordance with the opinion (Bompa 1983: 14) factors that influence the performance or performance of athletes include: the quality of training, knowledge, motivation, knowledge of the coach, the ability of athletes, talents, facilities, and matches. The same thing is in accordance with the problems discussed in the results of research from Imran Akhmad: 2015 that there is a significant influence between achievement motivation, quality of training on athletes' achievement.

The Benefits of Research Theoretically: As a provision to increase the knowledge and insight of researchers, as input for the academic community of Medan State University, especially in the Postgraduate program majoring in sports Education, as reference material for other researchers who will reexamine similar studies,

Practically: As an input for readers, administrators, and trainers, athletes in sports coaching achievements in PPLP North Sumatra, Knowing the constraints, and policies in sports coaching achievements in the North Sumatra PPLP, As a barometer for other PPLP regions.

\section{RESEARCH METHODOLOGY}

The study was carried out in PPLP North Sumatra having its address at Jalan Pembangunan Sekolah, No.7 Medan Selayang, and this research will be conducted in February 2018. The population in this research is all students under the guidance of PPLP North Sumatra 2017/2018 school year. The total number is 107 people.

The sampling technique in this study is purposive sampling. The method of determining the sample is by selecting / selecting athletes who have participated in the training / championships that are in the specified category. Among them: Have been coached at the training site for at least 2 years, have been fostered in PPLP for 2 years, never been a finalist in the event that was followed, The number of athletes who had met the criteria were: 31 people.

The method used in this study is a survey, with a correlational design approach through the regression equation that uses structural equations, namely the quality of influence between exogenous and endogenous variables. This technique is used to see how the contributions are directed by the path coefficients in each path diagram of the causal relationship between variables

This study involved 3 independent variables that will be examined to influence the dependent variable. The dependent variable is the achievement of North Sumatra PPLP athletes, while the independent variables are anxiety, athletic achievement motivation, and quality of training. Below is the chart.

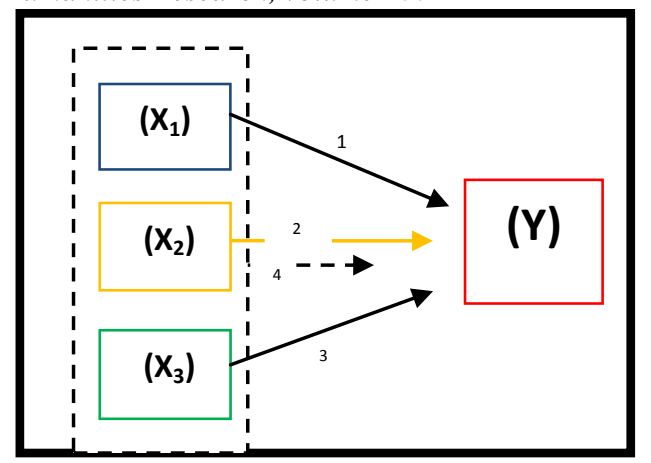

Fig. 3. The relationship between the variables affecting the affected variables

To get the data needed in depth about the achievements of North Sumatra PPLP athletes, it is necessary to document and prepare a test in the form of a Qustionnaire (Questionnaire) closed. The method used is Checklist (list of matches)

Data analysis techniques in this study use multiple regression analysis, because in this study there were 3 exogenous variables with 1 independent variable. Multiple regression analysis is a tool of forecasting analysis of the effect of two or more independent variables on the dependent variable to prove whether or not there is a function relationship or more (X1), (X2), (X3) ... (Xn) with one dependent variable (Riduwan 2010: 155) Multiple correlation formulas are as follows

Multiple regression equations (three independent variables) are formulated:

$\widehat{Y}=\alpha+b_{1} X_{1}+b_{2} X_{2}+b_{3} X_{3}$

\section{REFERENCES}

[1] Adisasmito, L.S. 2007. Mental Juara Jakarta : PT RajaGrafindo Persada

[2] Akhmad, Imran. 2015 : 78.96 Sport Special SchoolAchievement Athlete of Ragunan Volume 6, Issue 5, May 2017, International Journal of Science and Research (IJSR). ISSN (Online) : 2319-7064. Medan.

[3] Albadi, S.2011. Pengaruh Olahraga Kompetitif Terhadap Motivasi Berprestasi Dikalangan Siswa Sekolah Menengah Atas. Tesis tidak diterbitkan. Bandung : Program Pascasarjana Universitas Pendidikan Indonesia.

[4] Bakhtiar, S. 2015. Manajemen OlahragaAplikasinya Dalam Pembinaan Prestasi Olahraga Sumbar. Padang: UNP Press

[5] Baktiar, S. 2016. Jurnal Ilmu Keolahragaan Vol. 15 (1), Januari - Juni 2016:99-113

[6] Bompa, T.O.1990. Teory And Metodology Of Training. USA : Kendal/Hunt Publishing Company.

[7] Fitri, Dona Annisa dan Ifdil. 2015.Konsep Kecemasan (Anxiety) pada Lanjut Usia (Lansia) Volume 5 , Number 2, June 2016. ISSN: Print 1412-9760

[8] UU No. 3 Tahun 2005. Sistem Keolahragaan Nasional.Bandung : Citra Umbara.

[9] Yunis, Sabaruddin Bangun. 2017. Development Center and Student Sport Training of North Sumatera. Volume 6 Issue 4, April 2017. International Journal of Science and Research (IJSR) ISSN (Online): 2319-7064. Medan : Faculty of Sport Science, Medan State University 